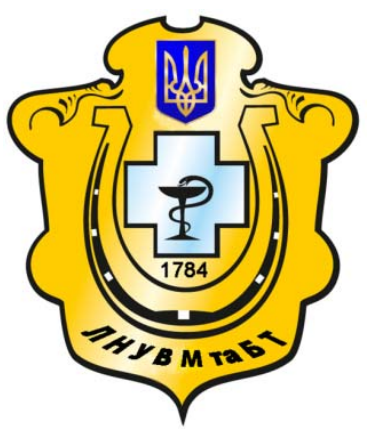

Науковий вісник Львівського національного університету ветеринарної медицини та біотехнологій імені С.3. Гжицького

Scientific Messenger of Lviv National University of Veterinary Medicine and Biotechnologies named after S.Z. Gzhytskyj

doi:10.15421/nvlvet7033

ISSN 2413-5550 print

ISSN 2518-1327 online

$\underline{\text { http://nvlvet.com.ua/ }}$

УДК 619:616.98:636.8

\title{
Дослідження терапевтичної ефективності гіперімунної сироватки проти каліцивірусної інфекції котів
}

\author{
Т.Г. Козленко, О.Г. Мартинюк \\ tatiana188981@gmail.com \\ Національний університет біоресурсів і природокористування Украӥни, \\ вул. Героїв Оборони, 15, м. Київ, 03041, Украӥна
}

В Украйні, як і в усьому світі, каліцивіроз є одним серед найбільш поширених інфекційних захворювань котів. Основною причиною иьвого є безперервний ріст інфекцій в популячї тварин, а також високийвідсоткок рецидивів гострого перебігу каліцивірозу в котів, які вже пройшли курс лікування. Крім того, перебіг каліцивірозу на сьогодні має хронічний характер. Тому, відповідно до вже існуючих схем лікування, необхідно розробляти нові більш ефективні, які направлені на елімінацію збудника шляхом призначення імуномодуляторів, антибактеріальних препаратів із одночасним застосуванням специффічних засобів, зокрема, гіперімунних сироваток проти калічивірозу котів.

У статті представлені експериментальні даніщодо вивчення різних схем комплексного лікування калічивірусної інфекціїкотів із застосуванням препаратів фоспреніл, тілозин і специфічної гіперімунної сироватки проти каліцивірусу. Лікувальні гіперімунні сироватки, крім їх безпосередньої реакиії з антигеном, проявляють імуномодулюючі властивості. Доведено, що використання специфічного глобулінув дозі 2 мл на тварину при лікуванні котів підвищує ефективність терапії на 25\% у порівнянні з використанням схеми, яка включала тільки антибіотик та імуномодулятор.

Ключові слова:каліџивіроз, коти, лікування, специфічний глобулін, імуномодулятори.

\section{Изучениетерапевтической эффективности гипериммунной сыворотки против калицивирусной инфекции кошек}

\author{
Т.Г. Козленко, А.Г. Мартынюк \\ tatiana188981@gmail.com
}

Национальный университет биоресурсов и природопользования Украины, ул. Героев Обороны, 15, г. Киев, 03041, Украина

В Украине, как и во всем мире, калицивироз является одним среди наиболее распространенных инфекционных заболеваний кошек. Основной причиной этого является непрерывный рост инфекиий в популяиии животных, а также высокий процент рецидивов острого течения калицивироза у котов, которые уже прошли курс лечения. Кроме того, ход калицивироза сегодня имеет хронический характер. Поэтому, в соответствии с уже существуюших схем лечения, необходимо разрабатывать новые более эффективные, направленные на элиминацию возбудителя путем назначения иммуномодуляторов, антибактериальных препаратов с одновременным применением специфических средств, в частности, гипериммунной сыворотки против калицивироза котов.

В статье представлены экспериментальные данные по исследованию различных схем комплексного лечения калицивирусной инфекции котек с применением препаратов фоспренил, Тилозин и специфической гипериммунной сыворотки против калииивируса. Лечебные гипериммунные сыворотки, кроме их непосредственной реакиии с антигеном, проявляют иммуномодулируюшие свойства. Доказано, что использование специфического глобулина в дозе 2 мл на животное в лечении кошек повышает эффективность терапии на 25\% по сравнению с использованием схемы, которая включала только антибиотик и иммуномодулятор.

Citation:

Kozlenko, T., Martyniuk, O. (2016). Examination of therapeutic effectiveness of hyperimmunne serum against feline calicivirus. Scientific Messenger LNUVMBT named after S.Z. Gzhytskyj, 18, 3(70), 141-145. 
Ключевые слова: калицивироз, коты, лечение, специфический глобулин, иммуномодуляторы.

\title{
Examination of therapeutic effectiveness of hyperimmunne serum against feline calicivirus
}

\author{
T. Kozlenko, O. Martyniuk \\ tatiana188981@gmail.com \\ National university of life and environmental sciences of Ukraine, \\ Heroyiv Oborony Str., 11, Kyiv, 03041, Ukraine
}

\begin{abstract}
In Ukraine, as elsewhere in the world, feline calicivirus is one of the most common infectious diseases of cats. The main reason is the continuous growth of infections in animal populations, and high recurrence interest of feline calicivirus in cats that have undergone treatment. In addition, nowadays, it is a chronic disease. Therefore, according to existing treatment regimens, there is a need to develop new, more effective, aimed at the elimination of the pathogen through the appointment of immunomodulators, antibiotics with simultaneous application of specific medicine, including hyperimmune serum against feline calicivirus.

The article presents experimental data on the study of various schemes of complex treatment for feline calicivirus using Fosprenil, Tylozine and specific hyperimmune serum against feline calicivirus. Apart from antigenic reaction, medical hyperimmune serum show immunomodulatory properties. It is proved that the use of specific globulin at a dose of $2 \mathrm{ml}$ per animal in the treatment of cats increases the effectiveness of therapy by $25 \%$ compared with the use of schemes that included only antibiotic and immune modulator. At the same time, it is known, that the use of globulin without antibiotics and immunomodulators does not show high therapeutic efficacy.
\end{abstract}

Key words: feline calicivirus, cats, treatment, specific globulin, immunomodulators.

\section{Ветуп}

В останні роки спостерігається підйом захворюваності кішок різними інфекціями, включаючи каліцивіроз та інфекційний ринотрахеїт (Rahmanina et al., 1994; Nedosekov, 2012; Nedosyekov et al., 2013; Golub et al., 2015; Sereda and Nedosekov, 2015).

Актуальність статті пов'язана 3 тим, що в Україні, як і в усьому світі, каліцивіроз є одним серед найбільш поширених інфекційних захворювань котів. Цезумовлено не тільки безперервним ростом інфекцій в популяції тварин, але й високим відсотком рецидивів гострого перебігу каліцивірозу в котів, які вже пройшли курс лікування. Крім того, перебіг каліцивірозу на сьогодні має хронічний характер (Makarov et al., 2012; Makarov et al., 2012; Golub et al., 2015).

Нарівні зімунопрофілактикою, лікування залишається одним із ефективних засобів контролю даної інфекції (Studdest, 1978; Nedosekov et al., 2010; Nedosekov, 2012; Nedosyekov et al., 2013; Stetsiura et al., 2016). Лікування каліцивірозумає спрямовуватися, перш за все, на відновлення захисного бар'єру слизових оболонок, боротьбу з вірусом, корекцію імунітету (стимуляція природної резистентності), захист від вторинних інфекцій, ліквідацію або ослаблення проявів захворювання (симптоматична терапія), а також на заміщення порушених фізіологічних функцій організму (замісна терапія) (Krylov, 2000; Nedosekov et al., 2009; Nedosekov, 2012). Крім того, при вірусних захворюваннях важлива правильна дієта, збалансований вміст у кормі вітамінів, макро- і мікроелементів. Це не лишескладовалікування, а й спосіб звільнення організму від накопичених за час хвороби шлаків та токсинів, що особливо важливо після тривалої анорексії або голодної дієти (Thompson et al., 1984).

На ранніх стадіях хвороби досить ефективні специфічні противірусні глобуліни і сироватки (Вітафел, Вітафел-C та ін.). Термін їх дії на вірусні частинки обмежений (тижденьвід початку захворювання) періодом вірусемії-перебуванням вірусу в крові. Окрім сироваток, на початкових стадіях хвороби ефективні препарати інтерферону та їх індукторів, імуностимулятори (Kreutz and Seal, 1995; Nedosyekov et al., 2010; Nedosekov et al., 2010; Nedosyekov et al., 2013).

При лікуванні каліцивірозу ефективною виявилася антибіотикотерапія. Попри те, що антимікробні препарати безсилі проти самого вірусу, вониефективно пригнічують супутню бактеріальну мікрофлору, яка ускладнює перебіг основного захворювання. На певному етапі хвороби вторинні інфекції починають відігравати провідну роль. Це стає помітним при скасуванні антибіотиків, коли захворювання загострюється і стан тварини погіршується. Одночасно з антибіотиками використовують аскорбінову кислоту, вітаміни групи В, А і Е в терапевтичних дозах (Studdest, 1978).

Таким чином, відповідно до вже існуючих схем лікування, необхідно розробляти нові більш ефективні, які направлені на елімінацію збудника шляхом призначення імуномодуляторів, антибактеріальних препаратів із одночасним застосуванням специфічних засобів, зокрема, гіперімунних сироваток проти каліцивірозу котів.

Метою наших досліджень було з'ясувати ефект від використання гіперімунної сироватки проти каліцивірозу.

\section{Матеріал і методи досліджень}

Дослідження проводили протягом 2012 - 2015 pp. на базі кафедри епізоотології та організації ветеринарної справи,інституту ветеринарної медицини НААН України та восьми клінік м. Києва.

Нами клінічно обстежено174котів, з яких 62 тварини індивідуального та 112 - групового утримання. Найбільшу частку хворих на каліцивіроз за нашими 
дослідженнями становили безпородні коти і кішки, тварини британської, персидської порід, а також російська сфінкс у віці від 1 місяця до 16 років.

Від цих тварин відбирали проби біоматеріалу (назальні, кон'юнктивальні і ротоглоткові змиви, а також зіскоби з укритих виразками ділянок слизових оболонок ротової порожнини), які заморожували і відправляли в лабораторію «Бальд» для проведення ПЛР.

Після постановки діагнозу тварин лікували комплексно з використанням отриманого нами експериментального зразка специфічної сироватки проти каліцивірозу кішок, імуномодулятора та антибіотика.

Як імуностимулятор нами було обрано Фоспренілпрепарат на основі поліпренолівхвої сосни. Володіє противірусним ефектом проти оболонкових вірусів. Модулює функціонування системи природної резистентності, стимулює імунну відповідь на вакцини, гепатопротектор, активізує еритропоез, обмін речовин, сприяє підвищенню приростів у молодняка.

Як антимікробний препарат нами було застосовано Тілозин. Останній належить до антибіотиків групи макролідів. Його дія полягає у інгібуванні синтезу білків. Тілозин активний проти грампозитивних (Staphylococcusspp., Streptococcusspp., Bacillusanthracis, Corynebacteriumspp., Clostridiumspp., Listeria, Erysipelothrixspp.) та деяких штамів грамнегативних мікроорганізмів, включаючи Наemophilusspp., Pasturellaspp. i Brucellaspp. Також Тілозин пригнічує дію деяких штамів Actinomyces, Mycoplasma, Chlamydia, Ureplasma i Rikettsia, що важливо, оскільки каліцивіроз найчастіше протікає в асоціації саме 3 цими інфекційними агентами.

3 метою вивчення лікувальних властивостей протикаліцивірусних глобулінів застосовували одержаний нами експериментальний зразок глобулінів як окремо, так і у складі комплексного лікування. Перед застосуванням глобуліну на тваринах ставили біопробу - вводили препарат глобуліну внутрішньошкірно, i через 30 хвилин, за відсутності алергічної реакції у місці введення, тваринам вводили терапевтичну доза препарату.

Лікування тварин проводили за чотирма розробленими схемами.

Тваринам першої групи вводили фоспреніл у дозі 0,2 мл на 1 кг маси тіла тварини впродовж 7 днів. Тваринам другої групи застосовували фоспреніл і Тілозин у дозах 0,2 мл на 1 кг маси тіла тварини впродовж 7 днів. Третій групі тварин вводили фоспреніл і Тілозин у дозах 0,2 мл на 1 кг маси тіла тварини впродовж семи днів і 2 мл глобуліну на тварину 5ти разово з інтервалом удві доби. Тваринам четвертої групи застосовували тільки специфічний глобулін у дозі 2 мл на тварину 5-ти разово з інтервалом 2 доби. П'ята група тварин була контролем, вводили по 0,2 мл фізіологічного розчину 1 раз на добу 7 діб.

Контроль ефективності лікування проводили методом ПЛР через чотири тижні після закінчення лікування. Отримані результати обробляли статистично, враховуючи вірогідність різниці показників $(\mathrm{p}<0,05)$ за критерієм Стьюдента.

\section{Результати та їх обговорення}

Нами були відібрані 33 тварини $з$ діагнозом каліцивіроз. У цих тварин відмічали лихоманку з підвищенням температури тіла до $40,5{ }^{\circ} \mathrm{C}$, явне зниження апетиту, млявість,рясні серозні виділення 3 носа i очей, підвищене слиновиділення.При обстеженні ротової порожнинина язику, губах, на піднебінні виявляли множинні виразки, наповнені рідиною.

На першому етапі наших дослідженьтваринлікували за схемою, яка включала імунотерапію, антибіотикотерапію та специфічну терапію, що полягала в застосуванні специфічного імуноглобуліну проти каліцивірусу.

Лікування тварин проводили за чотирма розробленими нами схемами (таблиця 1).

Схемилікуваннякаліцивірозукотів

\begin{tabular}{|c|c|c|c|}
\hline № п/п & Препарати & Доза та спосібвведення & Режим введення \\
\hline 1 & Фоспреніл & п/ш, 0,2 мл на 1 кгмаси & 1 раз на добу7діб \\
\hline \multirow{2}{*}{2} & Тілозін 50 & в/м, 0,2 мл на 1 кгмаси & 1 раз на добу7діб \\
& Фоспреніл & п/ш, 0,2 мл на 1 кгмаси & 1 раз на добу7діб \\
\hline \multirow{2}{*}{3} & Тілозін 50 & в/м, 0,2 мл на 1 кгмаси & 1 раз на добу7діб \\
& Фоспреніл & п/ш, 0,2 мл на 1 кгмаси & 1 раз на добу7діб \\
& Глобулін & в/м 2 мл на голову & 5 ін'єкцій через добу \\
\hline 4 & Глобулін & в/м 2 мл на голову & 5 ін'єкцій через добу \\
\hline 5 & Плацебо & 0,2 мл на голову & 1 раз на добу7діб \\
\hline
\end{tabular}

У процесі лікування серед тварин першої і четвертої груп відзначали незначне покращення, через 3 дні після початку введення препаратів температура тіла знизилась до норми, але покращення апетиту не відмічалося, виразки на слизовій оболонці ротової порожнини завдавали тваринам дискомфорту, ясна були припухлі й запалені. У тварин другої і третьої груп стан покращився вже на другу добу після початку лікування. Знизилась інтенсивність носових витікань, з'явився апетит, тварини стали жвавими, виразки в ротовій порожнині набули блідого кольору.
У жодної із тварин, яким було введено глобулін, не реєструвалась алергічна реакція ні за результатами біопроби, ні після введення глобуліну, що свідчить про низьку реактогенність лікувального препарату.

Результати досліджень 3 визначення терапевтичних властивостей глобуліну при лікуванні котів наведено в таблиці 2.

Термін, необхідний для відновлення епітелію та повної елімінації збудника, склав 4 тижні. 
Таблиия 2

Ефективність схем лікуваннякаліцивірозукотів

\begin{tabular}{|c|c|c|c|}
\hline Група & $\begin{array}{c}\text { Всього } \\
\text { тварин, } \\
\text { підданих } \\
\text { лікуванню }\end{array}$ & $\begin{array}{c}\text { Кількість тва- } \\
\text { рин, що } \\
\text { одужали }\end{array}$ & $\begin{array}{c}\text { Кількість } \\
\text { тварин, що } \\
\text { одужали, \% }\end{array}$ \\
\hline 1 & 5 & 2 & 40 \\
\hline 2 & 8 & 6 & 75 \\
\hline 3 & 9 & 8 & 88 \\
\hline 4 & 6 & 2 & 33 \\
\hline 5 & 5 & 0 & 0 \\
\hline
\end{tabular}

Як видно 3 таблиці 2, найкращий терапевтичний ефект був отриманий при використанні третьої схеми, яка передбачала застосування протикаліцивірусного глобуліну. У 8-ми тварин відмічали повну відсутність будь-яких клінічних ознак захворювання після пройденого курсу лікування. Після обстеження змивів зі слизових оболонок методом ПЛР через чотири тижні після закінчення курсу лікування у цих тварин одержані негативні результати. Це свідчить, що запропонована схема лікування сприяє повній елімінації збудника 3 організму, забезпечивши лікувальний ефект на 88\%. Крім того, дослідження показали, що у складі комплексної терапії каліцивірозу котів лікувальний ефект був на 25\% вищий, ніж при застосуванні антибіотику та імуномодулятора. Застосування специфічної сироватки проти каліцивірозу кішок, як єдиного засобу лікування,демонструвала низьку терапевтичну ефективність, яка склала $33 \%$, у той час як імунотерапія показала 40\% ефективність.

На даний час обгрунтована нами схема лікування хворих котів на каліцивіроз апробується в 3-хклініках м. Києва.

\section{Висновки}

Таким чином, нами було підібрано оптимальну схему лікування каліцивірозу котів та доведено доцільність використання протикаліцивірусного глобуліну у комплексній терапії, ефективність якої склала 88\%. Разом із тим показано, що застосування глобуліну без антибіотика та імуномодулятора не проявляє високої терапевтичної ефективності.

\section{Бібліографічні посилання}

Golub, Yu.S., Nedosekov, V.V., Albulov, O.I. (2015) Menedzhment ta marketyng u veterynarnij medycyni [Management and marketing in veterinary medicine], 644 (in Ukrainian).

Krylov, A.N. (2000) Biologicheskie svojstva vozbuditelya kalicivirusnoj infekcii koshek i razrabotka metoda diagnostiki bolezni [Biological properties of the originator cat calicivirus infection and development a method of the disease diagnosis]. Extended abstract of candidate's thesis. Moskva, 26 (in Russian).

Makarov, V., Nedosekov, V., Buchatskiy, L., Polischyuk, S. (2012) Synanhtropization of animals in megapolis [Synanhtropization of animals in megapolis] International scientific electronic journal Earth Bioresources and Quality of Life, 2. Retrieved from http://gchera-

ejournal.nubip.edu.ua/index.php/ebql/article/view/70

Nedosekov, V.V., Martyniuk, O.G., Bogdan, Yu.A. (2010) Sposib oderzhannya protyxlamidijnoyi giperimunnoyi syrovatky [A method of producing hyperimmune serum against chlamydia]. Patent na korysnu model № 47716. Byul № 4, vid 25 lyutogo (in Ukrainian).

Nedosyekov, V.V., Martyniuk, O.G., Ksonz, I.M., Tsivenko, T.M. (2010) Klinichni oznaky xlamidiozu domashnix myasoyidnyx [Clinical chlamydia signs of domestic carnivores] Veterynarna medycyna Ukrayiny. Veterinary Medicine of Ukraine, 6, 10-12 (in Ukrainian).

Nedosekov, V.V., Martyniuk, O.G., Palamar, M.I. (2010) Obgruntuvannya ta rozrobka sxemy likuvannya xlamidiozu sobak i kotiv [Justification and scheme development of chlamydia treatment of dogs and cats] Veterynarna biotexnologiya - Veterinary biotechnology, 17, 174-180 (in Ukrainian).

Nedosyekov, V.V., Martyniuk, O.G., Kozlenko, T.G., Slyvko, I.A., Slyvko, V.V. (2013) Vplyv imunomodulyatoriv na antyrabichnyj imunitet [Effect of immunomodulators for antirabic immunity] Naukovi praci PF NUBiP Ukrayiny - Research papers in NULES of Ukraine, 151 (in Ukrainian).

Nedosekov, V.V., Martyniuk, O.G., Palamar, M.I. (2009) Sposib likuvannya xlamidiozu domashnix miasoyidnyx. Patent na kory`snu model [A method for treating chlamydia of domestic carnivores] № 46248. Byul № 23, vid 10.12.2009 r. (in Ukrainian).

Rahmanina, M.M., Elizbarashvili, E.I., Ulasov, V.I., Mogilnyi, YU.I. (1994) Kaliciviroz koshek [Cats feline calicivirus] Veterinariya - Veterinary science, 9, 51-53 (in Russian).

Sereda, O.M., Nedosekov, V.V. (2015). Analiz evolyuciyi rozvy`tku ta poshy`rennya parvovirusnoyi infekciyi sered sobak ta kotiv [Analysis of the evolution and spread of parvovirus infection among dogs and cats] Naukovo-texnichny'j byuleten ' naukovo-doslidnogo centru biobezpeky' ta ekologichnogo kontrolyu resursiv APK - Scientific and technical bulletin of Research Center of biosafety and environmental control of resources AIC, Dnipropetrovs 'k, 56-62 (in Ukrainian).

Makarov, V., Nedosekov, V., Buchatskiy, L., Polischyuk, S. (2012). Synanhtropization of animals in megapolis [Synanhtropization of animals in megapolis] International scientific electronic journal Earth Bioresources and Quality of Life, 2. Retrieved from http://gchera-

ejournal.nubip.edu.ua/index.php/ebql/article/view/70

Nedosekov, V. (2012) Infectious animal pathology: problems and prospects [Infectious animal pathology: problems and prospects] International scientific electronic journal Earth Bioresources and Quality of Life, 1. Retrieved from http://gcheraejournal.nubip.edu.ua/index.php/ebql/article/view/14

Nedosekov, V. (2012) Reproductive and genetic features of vaccine strain $\mathrm{TC}-80$, the rabies virus [Reproductive and genetic features of vaccine strain $\mathrm{TC}-80$, the rabies virus] International scientific 
electronic journal Earth Bioresources and Quality of Life, 2. Retrieved from http://gcheraejournal.nubip.edu.ua/index.php/ebql/article/view/53

Stetsiura, L., Nedosekov, V., Martyniuk, O. (2016) Evaluation of manufacturing specification of antifungal vaccines [Evaluation of manufacturing specification of antifungal vaccines] «Edukacja Technika - Informatyka», 1.

Kreutz, L.C., Seal, B.S. (1995). The path way of feline calicivirus entry [The path way of feline calicivirus entry] Virus Research, Jan., 35(1), 63-70.
Studdest, M.R. (1978) Caliciviruses. Arch. virology, 58, 157.

Thompson, R.R., Wilcox, G.E., Clark, W.T., Jansen, K.L. (1984). Association of calicivirus infection with chronic gingivitis and pharyngitis in cats. J. Small Anim. Pract, 25, 207-210.

Стаття надійшла до редакиії 29.09.2016 